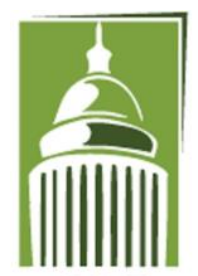

AR F

\section{Global Proceedings Repository}

American Research Foundation

ISSN 2476-017X

Available online at http://proceedings.sriweb.org

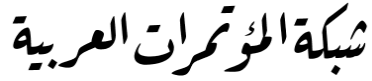

http://arab.kmshare.net/

The Ninth International Scientific Academic Conference

Under the Title "Contemporary trends in social, human, and natural sciences"

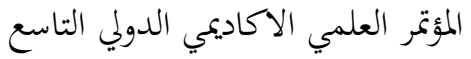

$$
\begin{aligned}
& \text { تحت عنوان "الاتحاهات المعاصرة في العلوم الاجتماعية، الانسانية، والطبيعية" } \\
& 17 \text { - } 18 \text { يوليو - تموز } 2018 \text { - اسطنبول - تركيا }
\end{aligned}
$$

http://kmshare.net/isac2018/

\title{
Genetic Stability and Viruses- Free Strawberry Plants Propagated via Repeated Meristem Culture
}

\author{
Nasser JY. Sholi, \\ Palestine Technical University, Kadoorie- Tulkarm, Palestine \\ P.O.Box. 7 - Jaffa street- Tulkarm
}

E mail: nassr3@yahoo.com

\begin{abstract}
Viruses cause great losses in agriculture. One of the major viruses affecting strawberry is Strawberry latent ringspot virus (SLRSV) and Strawberry mild yellow edge potexvirus (SMYEPV). Propagation via tissue culture is always accompanied with genetic instability. To produce a virus-free and genetically stable plant of commercial strawberry cultivar Hadas, a regeneration protocol was established using repeated shoot meristem from in vitro grown plant. Enzyme-linked immunosrbent assay (ELIZA) was used for virus's detection and Random amplified polymorphic DNA (RAPD) analysis was used to check for genetic stability of propagated plants. Results indicated that MS medium supplemented with BAP (2mg/ l) and $\mathrm{GA}_{3}(1 \mathrm{mg} / \mathrm{l})$ gave the maximum number of shoots (5 shoots/explant) with maximum average shoot length of $4.3 \mathrm{~cm}$. For rooting, MS medium supplemented with IBA at concentration of $1 \mathrm{mg} / 1$ gave the best results ( 7 roots /explant) and with average root length of $4.5 \mathrm{~cm}$. ELIZA results showed that repeated
\end{abstract}




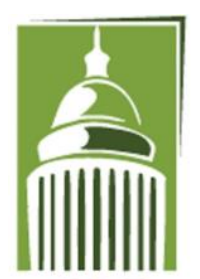

AR F

\section{Global Proceedings Repository \\ American Research Foundation}

ISSN 2476-017X

Available online at http://proceedings.sriweb.org

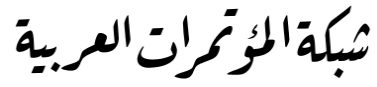

http://arab.kmshare.net/

meristem culture for a second time from in vitro grown plant produced $100 \%$ viruses free plant. RAPD analysis showed that the regenerated plants are genetically stable. In conclusion, repeated meristem culture was found to be more efficient in eliminating viruses and produce genetically stable plant

Keywords: Strawberry, Tissue culture, repeated meristem culture, Hadas , BAP, IBA.

\section{INTRODUCTION}

Strawberry (Fragaria ananassa Duch.) is one of perennial herbaceous plant consumed worldwide due to its excellent characteristics, such as delicious flavor, rich in variety of nutrients and vitamins (Yoshikawa and Converse, 1991).

Strawberry usually cultivated vegetatively, either through runners or separable plants. Therefore, the rate of multiple virus diseases infection is rising continuously year by year. Viruses affect strawberry plant, causing plant to be dwarfed, reduction in runner's numbers and in fruit quality leading in losses reached to $30 \%-80 \%$ in production, and even causing plant death (Hunter etal, 1990).

The best option available to tackle virus's infection in plants is to produce virus resistance varieties (Zhang, etal, 2000). At present, there are three main approaches used worldwide to remove strawberry viruses, namely, heat-treatment, anthers culture and meristem culture (Miller and Belken, 1963; Shabde and Murashige, 1977; Liu, 2008).

In heat treatment method, the plant was subjected to heat and humidity for a long time. This affect plant growth and even some plants tend to die. In addition, if the materials through heat treatment are used in tissue culture directly without proper disinfection, it will be more easily lead to pollution (Zhang etal, 2006).

Most researcher have come to an agreement that virus-free rate could reach $100 \%$ through anther tissue culture in the earlier researches. However, in the course of anther tissue culture, it has greatly affected by internal and external factors during culture. This in turn allows the possibility of somaclonal variation to arise including the variations of chromosome structures, chromosome numbers and on DNA molecular level (Zhang and Chen, 2007; Qia and Zhang, 2003; QU, 2005). Other reports showed that heat treatment combined with shoot tip culture, is very efficient in eliminating virus and produce virus- free plants which have many improvements and innovations (Gao, 1999; He etal, 2005; liu etal, 2009). 


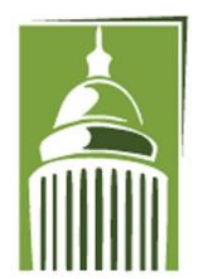

AR F

\section{Global Proceedings Repository \\ American Research Foundation}

ISSN 2476-017X

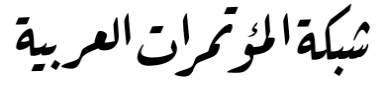

http://arab.kmshare.net/

Available online at http://proceedings.sriweb.org

Among these methods, apical shoot meristem was found to be the best method to generate virus- free plant since the invent of in vitro techniques, (Naz et al., 2009).Though it is time consuming and need special skill, but it is very safe and produce true to type plants and even can reach $100 \%$ in eliminating viruses, but there is always a chance of not reaching this percentage (Zhang etal, 2006, Zhang and Chen, 2007, Qu, 2005).

Regenerating plant via tissue culture is sometimes accompanied with somaclonal clonal variation. This case is also resent in strawberries (Fragaria x ananassa, Duch.), where several morphological abnormalities were detected. Changes include leaf color variants and dwarf plants, among others (Swartz et al., 1981; Sansavini et al., 1990; Irkaeva \& Matveena, 1997; Morozova, 2003). These variants pose a problem for production of uniform, true-to-type plants.

Currently, there are various methods available which are used to detect and monitor tissue culture-derived plants and cultivar identification. The most trusted methods are molecular marker techniques which used to identify the variation depending on the plant proteins, or specific region of DNA or DNA polymorphism. Among these molecular markers, Random Amplified Polymorphic DNA (RAPD) was being used in strawberries (Fragaria $\times$ ananassa Duch.) for clone identification and diversity studies [Gidoni, et al, 1994, Levi, et al., 1994, Graham, et al., 1996 Landry, et al, 1997, Degani, et al., 1998, Degani, etal., 2001 and Zebrowska and Tyrka, 2003).

In Palestine there are strong potential for cultivation. It has strong market and with good retail price. So far there is no well setup regeneration protocol or production of virus free mother stock for strawberry in Palestine and the only source of mother stock is from Israel. So the objective of this study is the production of viruses - free and genetically stable propagated plant via repeated meristem culture in strawberry cultivar (Hadas) in Palestine.

\section{MATERIALS AND METHODS}

\section{Plant source}




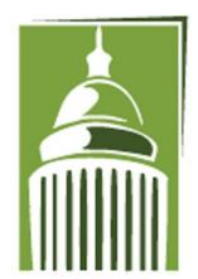

AR F

\section{Global Proceedings Repository \\ American Research Foundation}

ISSN 2476-017X

Available online at http://proceedings.sriweb.org

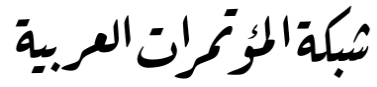

http://arab.kmshare.net/

Stock of commercial strawberry cultivar, namely Hadas was obtained from farmers and local nurseries.

\section{In vitro propagation of strawberry:}

Shoot tips were separated from runners, sterilized with hypochlorite $20 \%(\mathrm{v} / \mathrm{v})$ followed by 10 minutes with Mercuric chloride and 2 minutes in $70 \%$ alcohol. Washed three times in Sterile distilled water between each step. The explants were cultured onto the MS medium (Murashige and Skoog, 1962) supplemented with different concentrations of 6-benzylaminopurine (BA, $0.5,1,1.5,2$ and $2.5 \mathrm{mg} / \mathrm{l})$ with gibberellic acid $\left(\mathrm{GA}_{3}\right.$, $1 \mathrm{mg} / \mathrm{l})$, glucose $(30.0 \mathrm{~g} / \mathrm{l})$ and Bacto Difco agar $(7 \mathrm{~g} / \mathrm{l})$. The explants were kept at the temperature of $25 \pm$

$2{ }^{\circ} \mathrm{C}$ with light intensity of 2000 lux provided by fluorescent tube. The photoperiod was maintained at 16 hours light and 8 hours dark (16L/8D) and the relative humidity was $60-70 \%$. Afterwards, shoots were multiplied and subsequently rooted in vitro on the same medium with different concentration of Indol Butyric Acid (IBA, 0.5, 1, 1.5,2 and $2.5 \mathrm{mg} / \mathrm{l})$.

\section{Repeated meristem culture}

Shoot tips were removed from in vitro grown plant and treated the same as stated above.

\section{Viruses detection}

Commercial kit from Bioreba targeting (SLRSV) and (SMYEPV) was used.

\section{Genetic stability assessment}

The genetic stabilities of the explant donor plant and regenerated plants were analyzed using RAPD molecular markers selected randomly.

Bands with the same mobility were treated as identical fragments. Weak bands with negligible intensity and smear bands were both excluded from final analysis.

\section{DNA extraction}




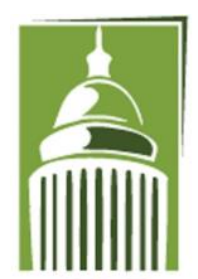

AR F

\section{Global Proceedings Repository \\ American Research Foundation}

ISSN 2476-017X

Available online at http://proceedings.sriweb.org

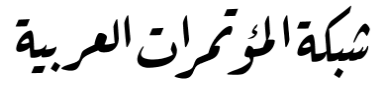

http://arab.kmshare.net/

Genomic DNA was isolated from randomly selected plant using Qiagen commercial Kit according to manufacturer instruction from the control (original) plant which used as a source of explant and regenerated plant. DNA quality and quantity was detected by spectrophotometry and gel electrophoresis

\section{PCR conditions:}

The amplification procedure was performed using a set of 7 primers randomly selected (Operon Technology, USA), the samples were prepared for amplification using DreamTaq PCR Master Mix (2x) (Fermentas), a ready to use solution containing the polymerase, buffer, $\mathrm{MgCl} 2$ and dNTPs, solution $1 \mu \mathrm{M}$ of each primer and $40 \mathrm{ng}$ of genomic DNA and ddMQ water was added to a final volume of $25 \mu \mathrm{l}$.

PCR reaction was conducted using a Perkin Elmer 2400 (Germany) thermocycler programmed for 40 cycles as follows: $94^{\circ} \mathrm{C} / 5 \mathrm{~min}(1 \mathrm{cycle}), 94^{\circ} \mathrm{C} / 30 \mathrm{sec}, 37^{\circ} \mathrm{C} / 30 \mathrm{sec}, 72^{\circ} \mathrm{C} / 1 \mathrm{~min}(40 \mathrm{cycle})$ and $72^{\circ} \mathrm{C} / 7 \mathrm{~min}(1 \mathrm{cycle})$, then held at $4^{\circ} \mathrm{C}$. The amplification products of PCR were separated by gel electrophoresis in $2 \%$ agrose gels with $1 \times$ TBE buffer stained with gel red dye and visualized with UV transilluminator and photographed.

\section{RESULTS AND DISCUSSION}

\section{Effect of BAP on in vitro shoot regeneration}

The use of different concentrations of BAP has shown significant differences on a number of shoots/explants and shoots length. The highest average shoots number (5) and average shoot length $(4.3 \mathrm{~cm})$ was observed at the concentration of $2 \mathrm{mg} / \mathrm{l} \mathrm{BAP}$. In contrast explant cultured on MS free hormone medium was produced the minimum number of shoot $(1.2)$ and shoot length $(0.65 \mathrm{~cm})$.

Table 1 Response of strawberry explants to different BAP concentrations supplemented in MS medium on shoot induction. 
ISSN 2476-017X

Available online at http://proceedings.sriweb.org

\begin{tabular}{ccccc}
\hline Cultivars & $\begin{array}{c}\text { BAP Conc. } \\
(\mathbf{m g} / \mathbf{l})\end{array}$ & $\begin{array}{c}\text { No. of } \\
\text { inoculated } \\
\text { explants }\end{array}$ & $\begin{array}{c}\text { Average } \\
\text { Shoots number }\end{array}$ & $\begin{array}{c}\text { Average shoot } \\
\text { length (cm) }\end{array}$ \\
\hline Hadas & 0 & 20 & $1.2 \mathrm{~d}$ & $0.65 \mathrm{c}$ \\
& 20 & $2 \mathrm{c}$ & $3 \mathrm{~b}$ \\
& 20 & $2.4 \mathrm{bc}$ & $4 \mathrm{a}$ \\
& 20 & $3.5 \mathrm{~b}$ & $4.2 \mathrm{a}$ \\
& 20 & $5 \mathrm{a}$ & $4.3 \mathrm{a}$ \\
& 20 & $3.4 \mathrm{~b}$ & $3 \mathrm{~b}$
\end{tabular}

Means followed by different letters within a column are significantly different at $\mathrm{p}=0.05$ according to DMRT test.

Increasing level of BAP has adverse effect on shoot induction number as well as root length as being seen at BAP concentration of $0.5 \mathrm{mg} / \mathrm{l}$ where maximum shoot number was 3.4 and shoot length was $3 \mathrm{~cm}$. (Table 1) and Fig 1 A. 


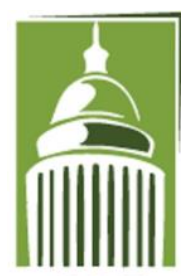

AR F

\section{Global Proceedings Repository \\ American Research Foundation}

ISSN 2476-017X

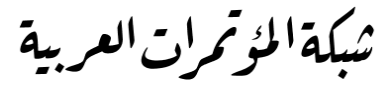

http://arab.kmshare.net/

Available online at http://proceedings.sriweb.org
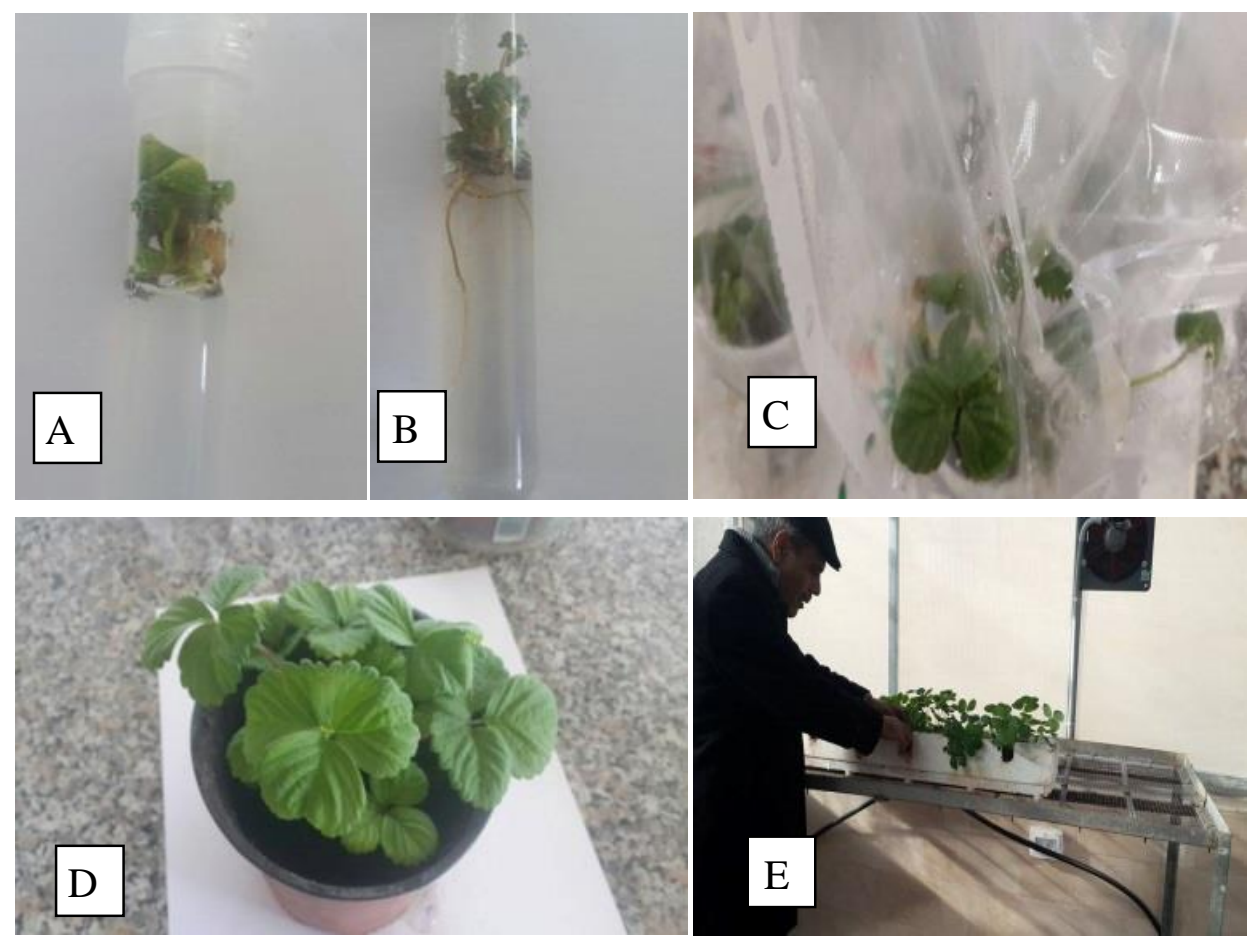

Fig1: stages of in vitro micropropagation. A, plantlets at induction medium. B, at rooting medium, C-D Plant hardening. F. Plants at green house.

Micropropagation of strawberry was reported about 30 years ago (Boxus, 1999). In our study B AP at $2 \mathrm{Mg} / \mathrm{l}$ gave the best response.. Meanwhile, Mahmoud et al. (1994) reported in their study that $0.5 \mathrm{mg} / \mathrm{l} \mathrm{BAP}$ supplemented to MS medium gave the best response. Other report supported the use $0.5 \mathrm{mg} / \mathrm{l}$ (Marcotrigiano et al. 1984 and Biswa et al., (2007). Asharfuzzaman et al. (2013) found that concentration of $0.5 \mathrm{mg} / \mathrm{l} \mathrm{BAP}$ in MS medium gave the highest average number of shoots (7) and the highest average length $(3.34 \mathrm{~cm})$. This may be attributed to use of different cultivar and genotypes

Other researcher found that TDZ at concentration of $1.5 \mathrm{mg} / \mathrm{l}$ produced the best results in three strawberry cultivars and $1.5 \mathrm{mg} / \mathrm{l} \mathrm{BA}$ and $0.5 \mathrm{mg} / \mathrm{l} \mathrm{Kin} \mathrm{revealed} \mathrm{highest} \mathrm{elongation} \mathrm{(Zakaria} \mathrm{H,} \mathrm{etal,} 2014$ ).

\section{Effect of IBA on in vitro root regeneration}




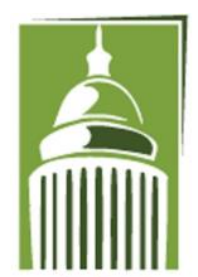

AR F

\section{Global Proceedings Repository \\ American Research Foundation}

ISSN 2476-017X

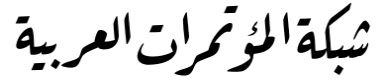

http://arab.kmshare.net/

Available online at http://proceedings.sriweb.org

The use of different concentrations of IBA has shown significant differences on a number of shoots/explants and shoots length. IBA at $1 \mathrm{mg} / \mathrm{l}$ showed the best performance in all the parameters studied (Table 2) and Fig. 1 B.

Table 2. Effect of different IBA concentrations in MS medium on root formation of strawberry cultivars

\begin{tabular}{cccc}
\hline Cultivar & IBA( mg/l) & Average root number & Average root length \\
\hline Hadas & 0 & $0 \mathrm{~d}$ & $0 \mathrm{~d}$ \\
& 0.5 & $2 \mathrm{c}$ & $3 \mathrm{~b}$ \\
1 & $7 \mathrm{a}$ & $4.5 \mathrm{a}$ \\
& 1.5 & $3.2 \mathrm{~b}$ & $1.2 \mathrm{c}$ \\
2 & $3 \mathrm{~b}$ & $0.8 \mathrm{~cd}$
\end{tabular}

Means followed by different letters within a column are significantly different at $\mathrm{p}=0.05$ according to DMRT test.

Roots were observed within 4 weeks of inoculation. These results are in conformity with Maliaricikova and Mokra (1986) who observed root formation within 3 - 4 weeks after plantlets inoculation in rooting media. Asahira and Kano (1977) also obtained the same results. No rooting was observed in auxin free media. Our results showed also, using IBA at $1 \mathrm{mg} / 1$ gave the best average number of roots (7) with root length of 4.5 cm (Fig. 1 B). While, Ashrafuzzaman et al. (2013) reported that MS medium with IBA at $0.5 \mathrm{mg} / \mathrm{l}$ gave the highest number (6) of roots/ explant and the longest $(3.05 \mathrm{~cm}$ ) roots. Increasing level of IBA above $1 \mathrm{mg} / \mathrm{l}$ decreased the average number of roots. Zakaria et al., 2014 used both NAA and IBA for rooting, but found that IBA at $1.5 \mathrm{mg} / \mathrm{l}$ in MS medium revealed higher response.

\section{Plant hardening}

Plant with healthy appearance was transferred into soil at tightly controlled - well protected lab environment and tested for virus infection. The hardened plant then transferred into greenhouse later on. The plant was treated according to farmer practice. 100 survival rates were obtained Fig 1(C-E). 


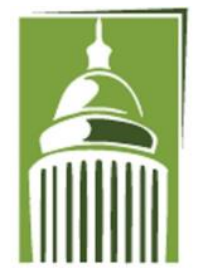

ARF

\section{Global Proceedings Repository \\ American Research Foundation}

ISSN 2476-017X

Available online at http://proceedings.sriweb.org

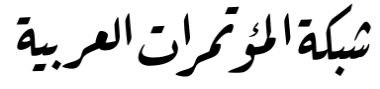

http://arab.kmshare.net/

\section{Viruses detection:}

The tested plant for free of viruses showed $100 \%$ virus free when using repeated meristem subculture compared with $90 \%$ when using single meristem culture (Fig 2).

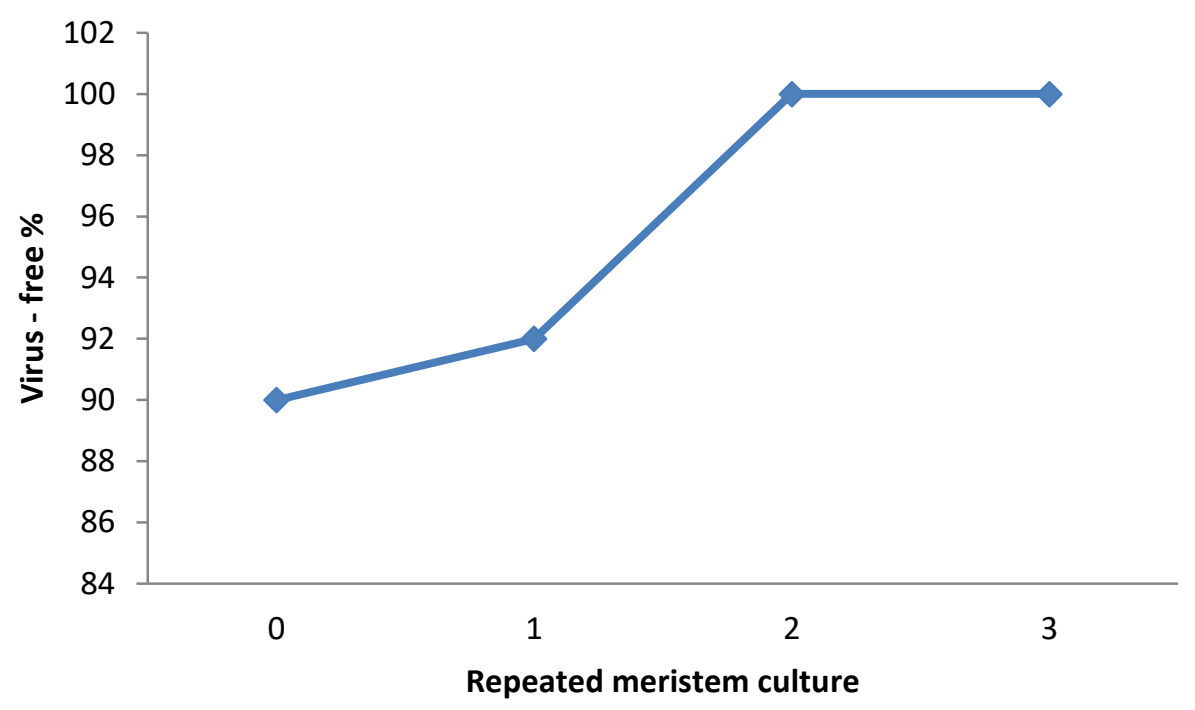

Fig 2: Effect of repeated meristem culture on virus elimination in strawberry cultivar Hadas.

The results clearly show that repeating meristem culture 2 times gave rise to $100 \%$ virus -free plants without affecting survival rate. When comparing our result with other methods; meristem culture obtained from heat treated plant affect survival rate of meristem regeneration as being showed by (Huifeng Jia and Haoru Tang, 2014). They found that maximum virus- free rate was $86 \%$ with survival rate of $78.7 \%$. The application of heat treatment alone was found to be not completely inactivating all kinds of strawberry viruses (Sairam, and Srivastava, 2001). In our case, repeated meristem culture could insure $100 \%$ viruses free without heat treatment. 


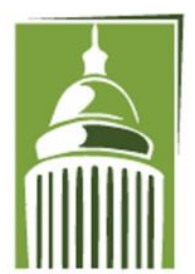

A R F

\section{Global Proceedings Repository}

American Research Foundation

ISSN 2476-017X

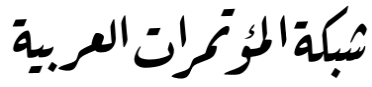

http://arab.kmshare.net/

Available online at http://proceedings.sriweb.org

\section{Genetic stability:}

On the basis of the number, intensity and reproducibility of RAPD bands four primers (OPK7, OPK6, OP3 and OP11) were selected out of the 10 primers, which were previously tested (Data not shown)

The extracted DNA from both in vitro derived plant and original plant ( mother) as control was used for RAPD analysis used, in vitro-derived plantlets. Figure 3 demonstrates the RAPD profiles obtained with three different primers (OPH-18, OPC-01 and OPD-01 and OPC-02). The result shows that OPH-18, OPC01 and OPD-01 are polymorphic. OPH-18, OPC-01 showed missing band in sample number 1 pointed by arrow. Primer OPD-01 and OPC-02 produced no differed between control and tested plants. Other tested primers did not produce any difference in banding pattern between control and meristem culture propagated plant as in OPD01 and OPC01 showed only one band differences, while primer 3 and primer show no difference in banding pattern.

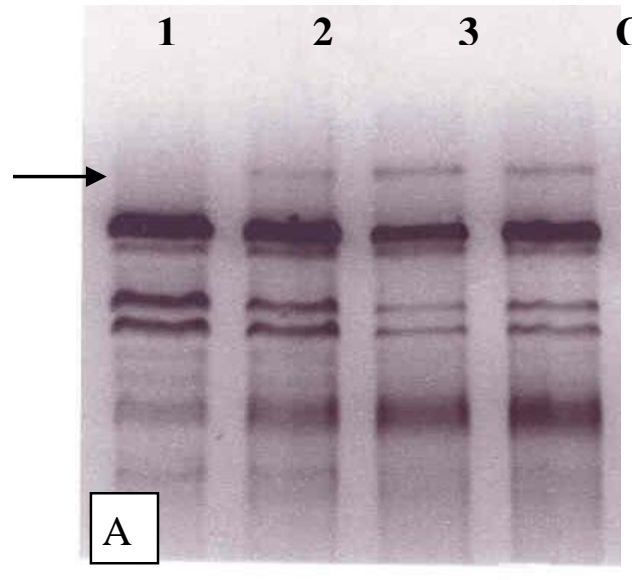

OPH-18:

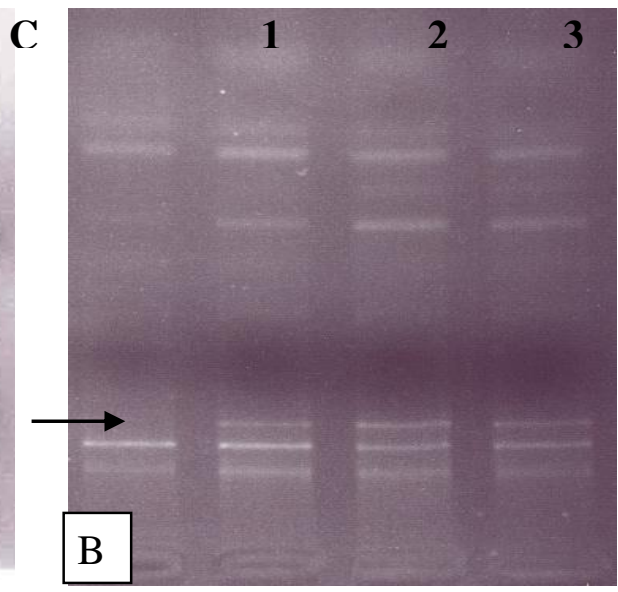

OPC-01: 


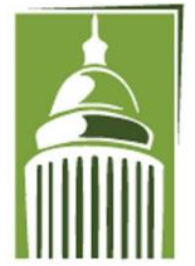

AR F

\section{Global Proceedings Repository \\ American Research Foundation}

ISSN 2476-017X

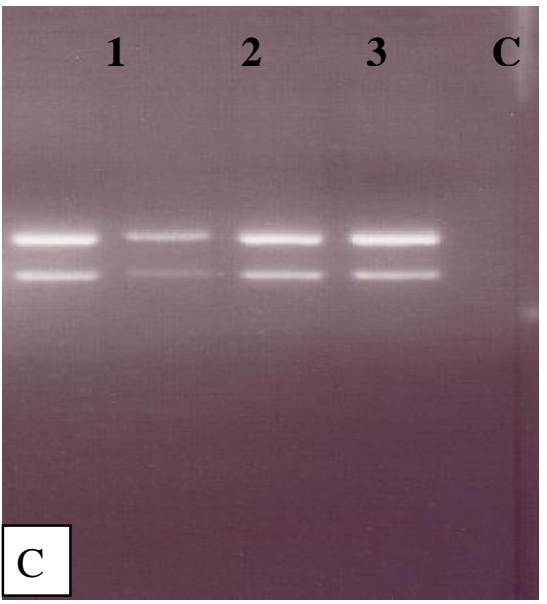

OPC-02:

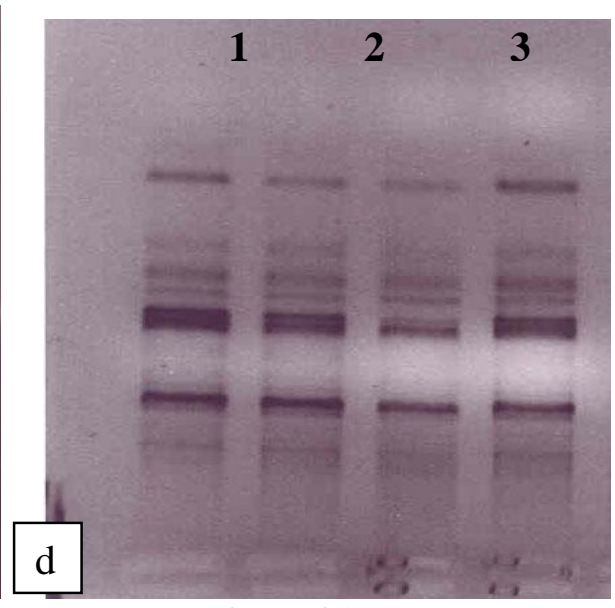

OPD-01

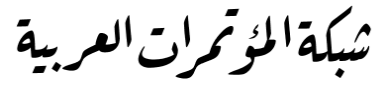

http://arab.kmshare.net/

Available online at http://proceedings.sriweb.org

Fig 3: Agarose gel showing random amplified polymorphic DNA amplification profiles of cultivars analyzed obtained with primer OPH (A), OPC0.1 (B) and OPC02 (C) AND opd01. Lane 1, 2, 3 are sample and C control.

In our study only 2 primers could detect the small difference between control and samples, while other primers could not. Studies by Zebrowska and Tyrka found only three primers and Gaafar and Saker (2006) found only 4 primers were polymorphic and could generate polymorphism among strawberry cultivars. While, Degani, et al, 2001 tested 10 primers and found that 100\% of the RAPD markers are polymorphic and was able to distinguish among 41 strawberry cultivars, of which the 19 in this study comprise a subgroup.

Though, RAPD markers are generally considered less reproducible or more prone to error, than AFLP markers (Jones et al., 1997) in our case it was able to discriminate the small difference between the control and meristem tissue culture derived plant

\section{Conclusion:}

Regeneration of strawberry Cultivar Hadas was successfully established. Repetitive meristem culture 2-3 cycles were found to be most effective in eliminating the viruses and produce genetically y stable plant as confirmed by RAPD analysis.

Acknowledgment: Deep thank for Palestine Technical University- Kadoori for financial support 


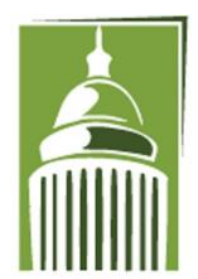

A R F

\section{Global Proceedings Repository \\ American Research Foundation}

ISSN 2476-017X

Available online at http://proceedings.sriweb.org

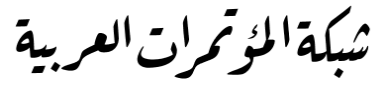

http://arab.kmshare.net/

\section{References:}

Asahira, T., Kano, Y.(1977) Shoot formation from cultured tissue of strawberry fruits. J. Jap. Soc. Hort. Sci. 46 (3): $317-324$

Ashrafuzzaman, Faisal, S. M, Yadav, D., Khanam, D., Raihan, F. (2013) Micropropagation of strawberry (M.Fragaria ananassa) through runner culture. Bangladesh J. Agril. Res. 38(3): 467-472, September 2013

Biswas, M.K., Hossain, M., Islam, R. (2007) Virus-free plantlets production of strawberry through meristem culture, World Journal of Agricultural Science 3: 757-763.

Boxus, P. (1999) Micropropagation of strawberry via axillary shoots proliferation. In: Plant Cell Culture Protocols. Methods in Molecular Biology. Part III. Plant Propagation In vitro. Hall R. D. (ed.) Humana Press Inc., Totowa NJ 111: 103-114

Degani, C., Rowland, L.J., Saunders, J.A., Hokanson, S.C., Ogden, E.L., Golan-Goldhirsh A and Galletta, G.J. (2001). A comparison of genetic relationship measures in strawberry (Fragaria x ananassa Duch.) based on AFLPs, RAPDs and pedigree data Euphytica, 117: 1-12.

Degani, C., Rowland, L.J., Levi, A., Hortynski J.A and. Galletta, G.J. (1998). DNA fingerprinting of strawberry (Fragaria $\times$ ananassa) cultivars using randomly amplified polymorphic DNA (RAPD) markers. Euphytica, 102: 247-253.

He, H.L, Yang, J., Cai, R, Pan, J.S. (2005). Effect of shoot tip culture on virus-free of strawberry, Northern Horticulture 5: 79-81. (In Chinese)

Huifeng. J., Haoru (2012).Effect of heat treatment combined with shoot tip culture on virus free of Arena strawberry. Journal of Life Sciences 6: 168-174

Hunter, B.G., Richardson, J., Dietzgen, R.G., Karu, A., Sylverster, E.S. (1990). Purification and characterization of strawberry crinkle virus, Phytopathology 80: 282-287.

Gao, S.L. (1999). Improved virus-free techniques of strawberry heat treatment meristem-tip and application of virus-free plants, Jiangsu Agricultural Sciences 3: 63-64. (In Chinese).

Gidoni, D., Rom, M., Kunik, T., Zur, M., Izsak, E., Izhar S. and Firon, N.( 1994). Strawberry-cultivar identification using randomly amplified polymorphic DNA (RAPD) markers. Plant Breed., 113: 339-342.

Graham, J., McNicoll R.C. and McNicoll, J.W. (1996). A comparison of methods for the estimation of genetic diversity in strawberry cultivars. Theor Appl. Genet., 93: 402-406. 


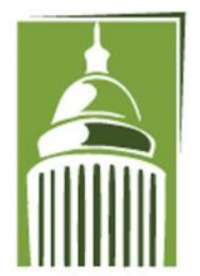

A R F

\section{Global Proceedings Repository \\ American Research Foundation}

ISSN 2476-017X

Available online at http://proceedings.sriweb.org

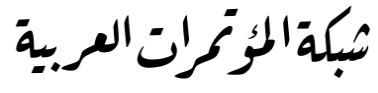

http://arab.kmshare.net/

Landry, B.S., Rongqi, L., Khanizadeh, S. and Dijkstra, J. (1997). Classification of 75 strawberry cultivars and breeding lines using RAPD markers Acta Hort., 439: 101-105.

Levi, A., Rowland, L.J. Galletta, G.J. . Martelli G .,Greco, I. (1994). Identification of strawberry genotypes and evaluation of their genetic relationships using randomly amplified polymorphic DNA (RAPD) analysis. Adv. Strawberry Res., 13: 36-39

Liu, J, Liu, X.L, Hu, F.R, Zhao, H., Zhu, H.F. (2009). Effect of heat treatment combined with shoot tip culture on virus-free of strawberry, Zhejiang Agricultural Sciences 6 (2009) 1088-1089. (In Chinese)

Mahmoud, S. Rashid, H., Quraishi, A., Iqbal, N., Arjumand, S.S. (1994). Clonal propagation of strawberry through tissue culture. Pakistan J. Agric Res. 15 (1) 54- 59

Maliaricikova, V., Mokra, A. (1986). Clonal propagation of strawberry in vitro. Ved. Pra. Vyskum. Usta. Ovecny. Okrasn. Dre Boj. 6: 117-123

Marcotrigiano, M., Swartz, H.J., Gray, S.E., Tokaricky, D. Popenoe, J. (1984). The effect of benzylaminopurine on the in vitro multiplication rate and subsequent field performance of tissue culture propagation strawberry plant. Adv. Strawberry Prod. 3 (spring): 23-25.

Murashige, T., Skoog, F. A. ( 1962). Revised medium for rapid growth and bioassays with tobacco tissue cultures. Physiol Plant, 15:473 - 97

Miller, P.W, Belken, R.O (1963). Elimination of yellow edge, crinkle, and vein banding viruses and certain virus complexes from strawberries by excision and culturing of apical meristems, Plant Disease Report 47 (1963) 298-300.

Naz, S, Siddiqui, F.A, Ali, A., Iqbal, J. (2009). Virus indexation of In vitro regenerated sugarcane plants. Pak. J. Bot., 41(4): 1931-1939.

Qu, H.J. (2005). Technology of strawberry plants by anther culture, Anhui Agricultural Science Bulletin 11 (3): 42-43. (In Chinese)

Shabde, M, Murashige, T. (1977). Hormonal requirements of excised Dianthus caryophyllus L. shoot apical meristem invitro, Am. J. Bot. 64: 443-448.

Sairam, R.K. and Srivastava, G.C. (2001).Water Stress Tolerance of Wheat (Triticum aestivum L.): Variations in Hydrogen Peroxide Accumulation and Antioxidant Activity in Tolerant and Susceptible Genotypes. Journal of Agronomy and Crop Science , 186, 63-70. 


\section{Global Proceedings Repository \\ American Research Foundation}

ISSN 2476-017X

Available online at http://proceedings.sriweb.org

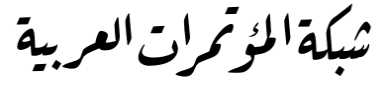

http://arab.kmshare.net/

ARF

Zakaria, H, Hussein, GM., Abdel-Hadi, AH, Abdallah, NA.( 2014). Improved regeneration and transformation protocols for three strawberry cultivars. GM Crops Food. Jan-Mar ;5(1):27-35

Zhang, Q, Jia, Z.K, Sun, W.H, Sun, Y, Tan, Y.J. ( 2000). Strawberry virus disease and no virus seedling production, Northern Horticulture 2: 1-3.

Zhang, L.P, Chen, H. (2007) Research progress of anther culture in horticultural plants, Journal of Anhui Agricultural Sciences 35: 5140-5142. (In Chinese)

Zebrowska, J.I. and Tyrka, M. (2003). The use of RAPD markers for strawberry identification and genetic diversity studies. Food Agr. \& Environ., 1: 115-117.

Yoshikawa, N. R.H. (1991). Converse, Purification and some properties of strawberry mottle virus, Annals of Applied Biology 118: 565-576. 